\title{
Effect of Ethephon Spray Treatments on Mechanical Harvesting and Oil Composition of 'Arbequina' Olives
}

\author{
J. Touss, J. Lloveras' ${ }^{1}$ and A. Romero \\ Institut de Recerca i Tecnologia Agroalimentàries-Centre de Mas Bové, Apartat 415, 43280 Reus, Spain
}

Additional index words. Olea europaea, fruit removal force, fruit drop, growth regulator, leaf drop

\begin{abstract}
Ethephon was applied at $0,625,1250,1875$, and $2500 \mathrm{~m}^{\circ}$ gliter $^{-1}$ in 2 consecutive years to 'Arbequina' olive trees to determine its effect on fruit removal with mechanical harvesting and on fruit oil composition. Ethephon increased the mechanical harvesting efficiency by $20 \%$. Ethephon at 1250 and $1875 \mathrm{mg} \cdot$ liter $^{-1}$ were the optimum treatments, resulting in $63 \%$ and $66 \%$ of the olives being mechanically harvested, respectively, with a preharvest olive drop of $10 \%$ and $11 \%$. Leaf drop (4.6 and $4.8 \mathrm{~kg} /$ tree fresh weight, respectively) at these concentrations did not reduce flowering the following year. Oil acidity, peroxide value, and fatty acid composition were affected little by ethephon and the values observed were within the range of normal annual variation. These results suggest that ethephon did not modify oil quality and that its use on traditionally pruned 'Arbequina' trees is not economically justifiable. Chemical name used: (2-chloroethyl)phosphonic acid (ethephon).
\end{abstract}

The 'Arbequina' olive tree is grown mainly in the northern Mediterranean areas of Spain and in Argentina. It is a self-pollinated tree characterized by frost resistance, flow vigor, small fruit size, and high productivity. 'Arbequina' olive oil is well known in the international oil market for its excellent taste and flavor (Tous, 1990). Further, 'Arbequina' olives are normally hand-picked and processed in a very short time. However, because of rising labor costs, mechanical harvesting is being introduced. The small size of the 'Arbequina' olive and the weeping habit of the branches reduce the energy transmission from mechanical vibration to the fruit, which decreases the efficiency of mechanical fruit removal (Tous and Romero, 1992). Three approaches can be taken to improve mechanical harvesting with a power vibrator: 1) change the tree shape and reduce canopy size by pruning, 2) use chemical treatments to enhance fruit abscission or 3) use a combination of 1 and 2 above (Martin, 1986; Ramalho and Pires, 1986).

Using ethephon to increase olive abscission has been reported for various olive cultivars (Antognozzi, 1981; Ben-Tal, 1987; Ben-Tal and Lavee, 1976; Cimato, 1982; Lavee et al., 1982; Martin, 1989), but there is no information on the response of 'Arbequina' olive to ethephon. Knowledge concerning the possible effects of ethephon on oil composition is limited (Cimato, 1988). The purpose of this study was to determine the effect of ethephon on mechanical harvesting efficiency and oil composition in 'Arbequina' olives.

\section{Materials and Methods}

Field trials were conducted during two seasons (1990-1991) under nonirrigated conditions at the Mas Bové Agricultural Research Station in Reus, Spain, on the Mediterranean coast. Temperatures and rainfall during the growing seasons are shown in Table 1.

Seventy-year-old 'Arbequina' trees were used for the experiment. Trees were an average height of $4 \mathrm{~m}$ and had a canopy

Received for publication 18 June 1993. Accepted for publication 22 Oct. 1993. We thank J. Clavé, A. Pérez, H. Riedl, and L Romagosa for their statistical and technical assistance. The cost of publishing this paper was defrayed in part by the payment of page charges. Under postal regulations, this paper therefore must be hereby marked advertisement solely to indicate this fact.

'Current address: UdL-IRTA, Rovira Roure 177, 25006 Lleida, Spain. diameter of $5.3 \mathrm{~m}$. The statistical design was a completely randomized block with four replications. Each replication consisted of an individual tree, with at least one border tree between treated trees. The same trees were used throughout the the experiment. The treatments consisted of ethephon applied at concentrations of 0 , $625,1250,1875$, and $2500 \mathrm{mg} \cdot$ liter $^{-1}$ a.i., formulated as Ethrel (480 g.liter ${ }^{-1}$ ). Each treatment (four trees) received a total of 25 liters of spray solution with $1 \mathrm{ml}$ of surfactant (nonylphenol polyethylene glycol, $20 \mathrm{~g} \cdot \mathrm{liter}^{-1}$ ) applied with a handgun and adjusted to $\mathrm{pH} 7$ with $0.1 \mathrm{~m}$ potassium phosphate. Control trees were sprayed with a similar volume of buffered water. The trees were sprayed at $\approx 0900 \mathrm{HR}, 12$ days before harvest in 1990 and 7 days before harvest in 1991. The harvest dates were 3 Nov. 1990 and 29 Nov. 1991. In 1991, $0.3 \mathrm{~mm}$ of rainfall occurred $7 \mathrm{~h}$ after the treatments were applied.

A net was installed under each tree after sprays were applied to collect olives or leaves that abscised before harvest. Preharvest dropped olives and leaves were weighed (fresh weight) separately before mechanical harvesting.

To evaluate the relative amount of leaf drop caused by the different treatments, two trees were completely defoliated with paraquat in 1991, their leaves were weighed, and the dry matter (DM) content was determined. The DM of leaves from trees treated with ethephon was also calculated in 1991 using samples of leaves from six randomly selected trees. The DM content of the samples was calculated by oven-drying a $50-\mathrm{g}$ subsample at $80 \mathrm{C}$ for $24 \mathrm{~h}$. Olives were harvested at the normal time and ripening stage for the area when $70 \%$ to $90 \%$ of the olives was dark violet. The fruit removal force (FRF) was determined the day before harvesting on 25 olives per tree with a Chatillon dynamometer.

Trees were mechanically harvested with a tractor-mounted trunk shaker. The shaker was attached to the tree trunk and operated for 10 to $12 \mathrm{sec}$ to remove fruit. Olives remaining on the trees after vibration were hand-picked to determine total production. Leaves removed during mechanical harvesting or handpicking were also weighed. For statistical analysis, harvested and dropped fruit and leaf data were expressed as percentages to eliminate the effects of individual tree size and production.

To assess the possible effects of leaf drop on the following year's bloom, the level of flowering was visually graded on a $\mathrm{O}$ to 10 scale, where $10=$ heavy bloom and $\mathrm{O}=$ no bloom. This was done 
Table 1. Average monthly and annual temperatures $\left({ }^{\circ} \mathrm{C}\right)$ and rainfall $(\mathrm{mm})$ in Reus, Spain, during the experiment and temperatures and rainfall on the day of ethephon treatment.

\begin{tabular}{|c|c|c|c|c|c|c|c|c|}
\hline & \multicolumn{4}{|c|}{1990} & \multicolumn{4}{|c|}{1991} \\
\hline & $\operatorname{Max}$ & Min & Mean & Rain & $\operatorname{Max}$ & Min & Mean & Rain \\
\hline$\overline{\text { September }}$ & 28.7 & 16.9 & 22.8 & 0 & 27.7 & 17.6 & 22.6 & 171 \\
\hline October & 26.5 & 15.1 & 20.8 & 4 & 26.6 & 14.1 & 20.3 & 8 \\
\hline November & 20.0 & 9.2 & 14.6 & 106 & 20.2 & 12.7 & 16.4 & 165 \\
\hline Annual & 23.4 & 12.0 & 17.7 & 329 & 23.7 & 12.1 & 17.9 & 670 \\
\hline Treatment day & 23.0 & 14.0 & 18.5 & 0 & 15.0 & 14.0 & 14.5 & 0.3 \\
\hline
\end{tabular}

in late April 1991 and 1992, the years after ethephon treatment.

To evaluate the possible effects of ethephon on oil composition, samples of olive oil from trees receiving $2500 \mathrm{mg} \cdot \mathrm{liter}^{-1}$ and no ethephon were analyzed for acidity, peroxide value, and fatty acid composition (Association of Official Analytical Chemists, 1984). Samples were taken from two replicates per treatment in 1990 and from four replicates in 1991. The oil was extracted by pressing the olives the day after harvest and was stored for a week at $4 \mathrm{C}$ before analysis.

\section{Results and Discussion}

The average olive yields were 40.5 and $65.2 \mathrm{~kg} /$ tree for 1990 and 1991, respectively, a result illustrating the small biennial bearing habit of the 'Arbequina' olive tree. Average olive yields did not vary significantly among treated trees in either year (data not shown), a result suggesting that the fruit yield increase in 1991 was independent of the concentration of ethephon applied in 1990.

The treatment $\times$ year interaction was not statistically significant for the percentages of preharvest dropped olives, mechanically harvested olives, hand-picked olives, or FRF (Table 2). FRF decreased linearly with increasing concentrations of ethephon, a result that agrees with earlier reports (Lavee et al., 1982). The highest FRF was $279 \mathrm{~N}$ for olives that received no ethephon and the lowest was $92 \mathrm{~N}$ for olives treated with $2500 \mathrm{mg} \cdot$ liter $^{-1}$. Ethephon also linearly increased preharvest fruit drop. Control trees dropped $6 \%$ of their fruit, whereas trees treated with $2500 \mathrm{mg} \cdot \operatorname{liter}^{-1}$ lost $20 \%$ of the olives.

Trees sprayed with ethephon at 1250 and $1875 \mathrm{mg} \cdot \mathrm{liter}^{-1}$ released the highest percentages of mechanically harvested olives, $63 \%$ and $66 \%$ of their crop, respectively (Table 2 ). The reason for the lower percentage $(58 \%)$ of fruit mechanically harvested on trees sprayed with ethephon at $2500 \mathrm{mg} \cdot \operatorname{liter}^{-1}$ is because this concentration increased preharvest fruit drop (20\%). Fruit removal in the present study is less than that reported by other authors (Lavee and Haskal, 1975; Ramalho and Pires, 1986), even though the temperature and humidity during the experiment were within the normal expected range (Martin, 1989).

The percentages of olives remaining on the trees after mechanical harvest decreased linearly with increasing concentrations of ethephon, and the highest percentages were $39 \%$ and $34 \%$ for trees treated with ethephon at 0 and $625 \mathrm{mg} \cdot \mathrm{liter}^{-1}$, respectively (Table 2 ). For the other treatments, fruit remaining on the tree after mechanical harvest ranged from $22 \%$ to $27 \%$ of the total yield. These high levels of unharvested olives and the low harvest efficiency could be due to the small size of 'Arbequina' olives and its weeping growth habit (Tous and Romero, 1992). If mechanical harvesting is to be used, trees will need corrective pruning to improve energy transmission during olive removal.

A detrimental side effect of ethephon on olive trees is excessive defoliation (Antognozzi, 1982; Ben-Tal and Lavee, 1976; Cimato, 1982; Martin, 1986). Our results show a significant linear increase in total leaf drop and preharvest leaf drop with ethephon treatments (Table 3).

The average DM of leaves from trees sprayed with ethephon and paraquat were 534 and $708 \mathrm{~g} \cdot \mathrm{kg}^{-1}$, respectively. When comparing the weight of dropped leaves from trees treated with ethephon vs. paraquat, the highest concentration of ethephon abscised $\approx 27 \%$ of the leaves, while the traditional hand harvesting method, consisting of combing the tree, abscised $\approx 15 \%$ of the leaves (ethephon at $0 \mathrm{mg} \cdot$ liter $^{-1}$ ).

The range of ethephon concentrations used in this study did not significantly affect flowering rate the year after treatment (Table 3 ). Some authors reported reduced flowering when defoliation exceeded $25 \%$ to $30 \%$ (Antognozzi, 1982; Martin, 1986). In a normal year, fruit set in $2 \%$ to $3 \%$ of the flowers is enough for a full crop (Lavee, 1986).

The oil composition (acidity, peroxide value, and fatty acid composition) of olives treated with ethephon at 0 and 2500 mg.liter ${ }^{-1}$ are presented in Table 4. Significant differences in the percentages of several fatty acids among years and concentrations were detected. These differences were mainly due to the results in

Table 2. Fruit removal force (FRF), yield, percentage of preharvest dropped olives (PDOs), mechanically harvested olives (MHOs), and hand-picked olives (HPOs) on 'Arbequina' trees treated with different concentrations of ethephon. Data are averages of 1990 and 1991.

\begin{tabular}{|c|c|c|c|c|c|}
\hline \multirow{2}{*}{$\begin{array}{l}\text { Ethephon } \\
\left(\mathrm{mg} \cdot \text { liter }^{-1}\right)\end{array}$} & \multirow{2}{*}{$\begin{array}{c}\text { Fruit } \\
\text { yield } \\
(\mathrm{kg} / \text { tree })\end{array}$} & \multirow{2}{*}{$\begin{array}{c}\text { FRF } \\
\text { (Newton) }\end{array}$} & PDOs & MHOs & HPOs \\
\hline & & & \multicolumn{3}{|c|}{ (\% of tree yield) } \\
\hline$\overline{0}$ & 46.6 & 2.79 & 6 & 55 & 39 \\
\hline 625 & 54.7 & 2.29 & 8 & 58 & 34 \\
\hline 1250 & 58.3 & 1.71 & 10 & 63 & 27 \\
\hline 1875 & 53.0 & 1.56 & 11 & 66 & 23 \\
\hline 2500 & 51.7 & 0.92 & 20 & 58 & 22 \\
\hline Best-fit model $^{2}$ & None & $\mathrm{L}$ & $\mathrm{L}$ & $\mathrm{Q}$ & $\mathrm{L}$ \\
\hline $\mathrm{r}^{2}$ & --- & 0.97 & 0.91 & 0.47 & 0.86 \\
\hline
\end{tabular}

${ }^{\mathrm{L}}=$ linear and $\mathrm{Q}=$ quadratic component at $\mathrm{P}<0.05$, respectively. 
Table 3. Total leaf drop (fresh weight), percentage of preharvest leaf drop (PLD), percentage of leaf drop during mechanical harvesting (MHLD), percentage of leaf drop during hand picking (HPLD), and flowering rates (FRs) for 'Arbequina' olive trees treated with different concentrations of ethephon. Data are averages of 1990 and 1991.

\begin{tabular}{|c|c|c|c|c|c|}
\hline \multirow{2}{*}{$\begin{array}{l}\text { Ethephon } \\
\left(\mathrm{mg} \cdot \text { liter }^{-1}\right)\end{array}$} & \multirow{2}{*}{$\begin{array}{c}\text { Leaf } \\
\text { drop } \\
(\mathrm{kg} / \mathrm{tree})\end{array}$} & PLD & MHLD & HPLD & \multirow[b]{2}{*}{$\mathrm{F} \mathrm{R}^{\mathrm{z}}$} \\
\hline & & \multicolumn{3}{|c|}{ (\% of total leaves dropped) } & \\
\hline 0 & 2.8 & 3 & 44 & 53 & 5.8 \\
\hline 625 & 3.4 & 6 & 64 & 30 & 5.6 \\
\hline 1250 & 4.6 & 5 & 65 & 30 & 5.7 \\
\hline 1875 & 4.8 & 13 & 60 & 27 & 4.9 \\
\hline 2500 & 5.0 & 12 & 60 & 28 & 5.1 \\
\hline Best-fit model $^{y}$ & $\mathrm{~L}$ & $\mathrm{~L}$ & $\mathbf{Q}$ & LQ & None \\
\hline$r^{2}$ & 0.96 & 0.86 & 0.62 & 0.83 & --- \\
\hline
\end{tabular}

${ }^{\mathrm{z}} 10=$ Heavy bloom, $0=$ no bloom.

${ }^{y} \mathrm{~L}=$ linear $\mathrm{Q}=$ quadratic component at $P<0.05$, respectively.

Table 4. Oil quality parameters and fatty acid composition of olives from trees treated with 0 and $2500 \mathrm{mg} \cdot 1$ liter $\mathrm{of}^{-1}$ ethephon in 1990 and 1991.

\begin{tabular}{|c|c|c|c|c|c|c|}
\hline \multirow{3}{*}{$\begin{array}{l}\text { Oil } \\
\text { parameters }\end{array}$} & \multicolumn{4}{|c|}{ Ethephon (mg.liter $\left.{ }^{-1}\right)$} & & \\
\hline & \multicolumn{2}{|c|}{0} & \multicolumn{2}{|c|}{2500} & \multicolumn{2}{|c|}{ Significance } \\
\hline & 1990 & 1991 & 1990 & 1991 & Year & Concn \\
\hline Acidity ( \% ) & 0.33 & 0.13 & 0.47 & 0.08 & $* *$ & $\overline{\text { NS }}$ \\
\hline Peroxide value (meq $\mathrm{O}_{2} / \mathrm{kg}$ ) & 11.60 & 3.70 & 11.85 & 4.97 & $* *$ & NS \\
\hline \multicolumn{7}{|l|}{ Fatty acids (\%) } \\
\hline 16:0 (Palmitic) & 15.94 & 13.97 & 11.09 & 13.87 & NS & $* *$ \\
\hline 16:1 (Palmitoleic) & 1.23 & 1.22 & 0.24 & 1.11 & $* *$ & $* *$ \\
\hline 17:0 (Margaric) & 0.14 & 0.15 & 0.13 & 0.15 & NS & NS \\
\hline 17:1 (Margaroleic) & 0.26 & 0.30 & 0.21 & 0.28 & $*$ & $* *$ \\
\hline 18:0 (Stearic) & 1.79 & 1.88 & 2.07 & 1.96 & NS & * \\
\hline $18: 1$ (Oleic) & 70.12 & 72.86 & 77.08 & 72.58 & NS & $* *$ \\
\hline 18:2 (Linoleic) & 9.03 & 8.23 & 7.04 & 8.48 & NS & $* *$ \\
\hline 18:3 (Linolenic) & 0.60 & 0.58 & 0.76 & 0.56 & $*$ & $*$ \\
\hline 20:0 (Arachidonic) & 0.39 & 0.38 & 0.39 & 0.37 & NS & NS \\
\hline 20:1 (Gadoleic) & 0.32 & 0.31 & 0.46 & 0.31 & $* *$ & $* *$ \\
\hline 22:0 (Behenic) & 0.12 & 0.13 & 0.12 & 0.12 & NS & NS \\
\hline 24:0 (Lirocenic) & 0.08 & 0.02 & 0.07 & 0.02 & $*$ & NS \\
\hline
\end{tabular}

$\overline{\mathrm{Ns},{ }^{*}, * *}$ Nonsignificant or significant $\mathrm{F}$ value at $P<0.05$ or 0.01 , respectively.

1990, because in 1991 there were no significant differences between treatments. In our study the variations in fatty acid composition between treatments were small and within the range of normal year-to-year variation. Cimato (1988) reported moderate changes in palmitic, linoleic, and oleic acid. Lavee and Haskal (1975), who treated 'Nabali' olives with ethephon at 1500 $\mathrm{mg} \cdot \mathrm{liter}^{-1}$, found that, at this rate, neither color nor taste of the oil was affected. In our study, the oil from both years and treatments could be classified as extra virgin according to international standards (International Olive Oil Council, 1990).

\section{Conclusions}

Using ethephon at 1250 and $1875 \mathrm{mg} \cdot \operatorname{liter}^{-1}$ on conventional 'Arbequina' olive trees increased the yield from mechanical harvesting by $20 \%$. These rates seem to be the most appropriate, because they increased the amount of harvested fruit without significantly enhancing preharvest leaf drop and did not adversely affect flowering the following year. These concentrations of ethephon are similar to that reported for other olive cultivars (Lavee and Haskal, 1975; Lavee et. al., 1982; Ramalho and Pires, 1986). However, further work is needed to improve the percentage of fruit removal, possibly by changing the tree shape. In our opinion, using ethephon on traditionally pruned 'Arbequina' olive trees is not economically justifiable. Ethephon had little effect on oil acidity, peroxide value, and oil fatty acid composition.

\section{Literature Cited}

Antognozzi, E. 1981. Risultati di trattamenti con prodotti cascolanti nelle raccolta delle olive e loro effetti sull' induzione antogena. Riv. Ortoflorofrutt. It. 65:393-402.

Antognozzi, E. 1982. Risultati di trattamenti con CEPA (ethephon) nella raccolta delle olive da mensa. Riv. Ortoflorofrutt. It. 66:121-133.

Association of Official Analytical Chemists. 1984. Official methods of analysis. vols. 1-2. Assn. Offic. Anal. Chem, Arlington. Va.

Ben-Tal, Y. 1987. Improving ethephon's effect on olive fruit abscission by glycerine. HortScience 22:869-871.

Ben-Tal, Y. and S. Lavee. 1976. Ethylene influence on leaf and fruit detachment in 'Manzanillo' olive trees. Scientia Hort. 4:337-344.

Cimato, A. 1982. Azione del CEPA su alcuni aspetti dells biologia fiorale dells cultivar di olivo 'Frantoio'. Riv. Ortoflorofrutt. It. 66:455-466.

Cimato, A. 1988. La qualità dell'olio vergine di oliva ed i fattori agronomici. Informatore Agrario 45:63-69.

International Olive Oil Council. 1990. Olive oil quality improvement. Collection technical handbook. Intl. Olive Oil Council, Madrid. 
Lavee, S. 1986. Olive, p. 261-276. In: P.S. Monselive (ed.). Handbook of fruit set and development. CRC Press, Boca Raton, Fla.

Lavee, S., B. Avidan, and Y. Ben-Tal. 1982. Effect of fruit size on the fruit-removal-force within and between olive cultivars. Scientia Hort. 10:27-32.

Lavee, S. and A. Haskal. 1975. Studies with ethephon for facilitating olive harvest. Scientia Hort. 3:163-171.

Martin, G.C. 1986. Olive harvest in California. Olivae 3:11-20.

Martin, G.C. 1989. Olive inflorescence, flower, fruit and leaf abscission with chemicals used for mechanical harvest. NATO ASI Ser. vol. H35, p. 33 1-348. In: D. J. Osborne and M.B. Jackson (eds.). Cell separation in plants. Springer-Verlag, Berlin.

Ramalho, J. and J.A. Pires. 1986. Recolección mecánica de la aceituna en Portugal. Olivae 13:24-33.

Tous, J. 1990. El Olive. Situación y perspectives en Tarragona. Diputación de Tarragona, Tarragona, Spain.

Tous, J. and A. Romero. 1992. Variety description of 'Arbequina'. Olivae 43:28-29. 